\title{
Morphometric Analysis of the Greater Palatine Foramen in Dry Southern Brazilian Adult Skulls
}

\author{
Análisis Morfométrico del Foramen Palatino Mayor \\ en Cráneos de Individuos Adultos del Sur de Brasil
}

Lopes, P. T. C.; Santos, A. M. P. V.; Pereira, G. A. M. \& Oliveira, V. C. B. D.

LOPES, P. T. C.; SANTOS, A. M. P. V.; PEREIRA, G. A. M. \& OLIVEIRA, V. C. B. D. Morphometric analysis of the greater palatine foramen in dry Southern Brazilian adult skulls.Int. J. Morphol., 29(2):420-423, 2011.

SUMMARY: The greater palatine foramen (GPF) conducts the greater palatine nerve, responsible for the innervation of the posterior hard palate. The morphometric knowledge of the GPF is essential in the anesthetic interventions required in maxillofacial surgical procedures. The aim of this study was to evaluate the location and shape of the GPF in dry skulls of adults from Southern Brazil. Male ( $\mathrm{n}=65)$ and female $(\mathrm{n}=29)$ skulls were studied, and the distance measurements from the middle of the GPF to the mid-sagittal plane (MSP) and to the posterior border of the hard palate (PBHP) were analyzed using a digital caliper and a ruler. The mean GPF-MSP distance in the right and in left sides of male skulls were $15.6 \mathrm{~mm}$ and $15.4 \mathrm{~mm}$, respectively, and in female skulls, $15.63 \mathrm{~mm}$ in the right side and $15.47 \mathrm{~mm}$ in the left. The mean GPF-PBHP distance on the right side was $3.5 \mathrm{~mm}$ in male skulls, and $3.1 \mathrm{~mm}$ in female skulls, and on the left side, $3.6 \mathrm{~mm}$ and $3.2 \mathrm{~mm}$ in male and female skulls, respectively. Student's t-test showed no significant difference in the GPF-MSP and GPF-PBHP mean distances when compared to gender and to the left and right sides. The predominant GPF shape was ovoid, followed by lancet or slit, and round. This study provides comparisons of ethnic data, which may help clinically in oral and maxillofacial anesthesia.

KEY WORDS: Greater Palatine Foramen; Skull; Brazilian Population; Osteometry.

\section{INTRODUCTION}

The greater palatine foramen (GPF) conducts the greater palatine nerve, responsible for the innervation of the posterior hard palate. In the literature it has been located in the angle between the horizontal lamina of the palatine bone and the posterior process of the hard palate (Heidegger, 1972); near the posterior border of the hard palate and medially to the posterior alveoli (Hamilton, 1982); in the posterolateral angle of the hard palate (Lockhart et al., 1983); in the most lateral point of junction of the maxillary palatine processes with the horizontal lamina of the palatine bones (Castro, 1985); in the hard palate at the level of the dihedral angle formed by the horizontal lamina of the palatine bone and the inner surface of the maxillary alveolar process, between the transverse suture and the posterior border of the hard palate (Ferreira et al., 1990); in the posterolateral angle of the palatine bone, next to the last molar (Rizzolo \& Madeira, 2006). However, the location of the GPF in adult human skulls has not been adequately described (Ajmani, 1994; Jaffar \& Hamadah, 2003; Saralaya \& Nayak, 2007).
Previous studies compared the mean measures of the points of reference in relation to the antimeres of the GPF, with the aim of verifying a possible bilateral asymmetry among them (Westmoreland \& Blanton, 1982; Ajmani; Sujatha et al., 2005; Methathrathip et al., 2005). The morphometric knowledge of the GPF is essential in the anesthetic interventions required in oral and maxillofacial surgical procedures. The aim of this study was to evaluate the location and shape of the GPF in dry skulls of adults from southern Brazil.

\section{MATERIAL AND METHOD}

94 skulls of adults from Southern Brazil, 65 male and 29 female, from the Laboratory of Human Anatomy of the Brazilian Lutheran University (ULBRA) were used. The distances from the middle of the GPF to the mid-sagittal 
plane (MSP) and from the middle of the GPF to the posterior border of hard palate (PBHP) were measured, according to Westmoreland \& Blanton. Measurements were performed by two researchers, separately. Subsequently, the data were compared and the mean numbers were obtained. Distance measurements were taken with a Mitutoyo digital caliper and a ruler. Statistical analysis were carried out using Student's t-test for paired and independent samples, revealing a significant difference when $\mathrm{p}<0.05$. This study was approved by the Ethics in Human Research Committee of ULBRA.

\section{RESULTS AND DISCUSSION}

GPF-MSP distance measurements: when comparing gender, there is no significant difference on the right side $(\mathrm{p}$ $=0.993>0.05)$ and on the left side $(\mathrm{p}=0.754>0.05)$ (Table I, A1, B1, A2, B2). Comparing the left and right sides, regardless of gender, there is no significant difference $(\mathrm{p}=$ 0.993> 0.05) (Table I, C1, C2).

Table I. Measurements of the distance from the middle of the greater palatine foramen to the midsagittal plane $(\mathrm{mm}$; mean \pm standard deviation). A1, right side in male skulls; A2, left side in male skulls; B1, right side in female skulls; B2, left side in female skulls; C1, right side in male and female skulls; $\mathrm{C} 2$, left side in male and female skulls.

$\begin{array}{ll}\text { A1 (65) } & 15.62 \pm 1.27 \\ \text { A2 (65) } & 15.37 \pm 1.37 \\ \text { B1 (29) } & 15.63 \pm 1.49 \\ \text { B2 (29) } & 15.47 \pm 1.51 \\ \text { C1 (94) } & 15.62 \pm 1.33 \\ \text { C2 (94) } & 15.40 \pm 1.41\end{array}$

GPF- PBHP distance measurements: when comparing genders, there is no significant difference on the right side $(\mathrm{p}=0.147>0.05)$ and on the left side $(\mathrm{p}=0.146>$ 0.05) (Table II, D1, D1, E2, E2). Comparing the left and right sides, regardless of gender, there is no significant difference $(\mathrm{p}=0.286>0.05)$ (Table II, F1, F2).
Table II. Measurements of the distance from the middle of the greater palatine foramen to the posterior border of the hard palate (mm; mean \pm standard deviation). D1, right side in male skulls; D2, left side in male skulls; E1, right side in female skulls; E2, left side in female skulls; F1, right side in male and female skulls; F2, left side in male and female skulls.

$\begin{array}{ll}\text { D1 (65) } & 3.50 \pm 1.21 \\ \text { D2 (65) } & 3.61 \pm 1.12 \\ \text { E1 (29) } & 3.10 \pm 1.24 \\ \text { E2 (29) } & 3.25 \pm 1.04 \\ \text { F1 (94) } & 3.38 \pm 1.22 \\ \text { F2 (94) } & 3.50 \pm 1.11\end{array}$

GPF shape: ovoid (56.9\%), followed by lance or slit (26.1\%), and round (17.0\%) were the shapes most commonly found on both sides. On the right side of male skulls, ovoid $(58.5 \%)$, lancet or slit $(27.7 \%)$, and round (13.8\%) shapes were found. On the left side, ovoid (58.5\%), lancet or slit (24.6\%), and round (16.9\%) shapes were the most commonly found. On the right side of female skulls, ovoid (51.7\%), lancet or slit (27.6\%), and round (20.7\%) shapes were found. On the left side, ovoid (55.2\%), lancet shape or slit (24.1\%), and round $(20.7 \%)$ shapes were found. Regardless of gender, on the right side ovoid (56.4\%), lancet or slit (27.7\%), and round $(15.9 \%)$ shapes were found. On the left side, ovoid $(57.4 \%)$, lancet or slit $(24.5 \%)$, and round $(18.1 \%)$ shapes were found (Table III).

The GPF-MSP distance showed variability in the literature from $14.44 \mathrm{~mm}$ to $16.0 \mathrm{~mm}$. Westmoreland \& Blanton recorded $8.14 \pm 0.07 \mathrm{~mm}$ on the right side and 15.4 $\pm 0.07 \mathrm{~mm}$ on the left on skulls of eastern India. Jaffar \& Hamadah measured $15.71 \pm 1.36 \mathrm{~mm}$ in Caucasian skulls. Wang et al. (1988) obtained $16.0 \mathrm{~mm}$ in Chinese skulls. Ajmani found $4.15 \pm 0.21 \mathrm{~mm}$ on both sides in Nigerian skulls, and $14.7 \pm 0.96 \mathrm{~mm}$ on the right side and $14.6 \pm 10.8$ $\mathrm{mm}$ on the left side in Indian skulls. Methathrathip et al. obtained $16.2 \pm 1.3 \mathrm{~mm}$ in both genders, and $16.4 \pm 1.4 \mathrm{~mm}$ in male and $15.9 \pm 1.3 \mathrm{~mm}$ in female Thai skulls. Saralaya \& Nayak recorded $0155 \pm 14.7 \mathrm{~mm}$ on the right side and

Table III. Shape of greater palatine foramen.

\begin{tabular}{crrrrr}
\hline Shape & \multicolumn{2}{c}{ Male skulls } & \multicolumn{2}{c}{ Female skulls } & $\mathrm{n}$ \\
& Right side & Left side & Right side & Left side & \\
\hline Round & 9 & 11 & 6 & 6 & 32 \\
Lancet/slit & 18 & 16 & 8 & 7 & 49 \\
Ovoid & 38 & 38 & 15 & 16 & 107 \\
$\mathrm{n}$ & 65 & 65 & 29 & 29 & 188 \\
\hline
\end{tabular}


$14.7 \pm 0,146 \mathrm{~mm}$ on the left, in South Indian skulls. Chrcanovic \& Custódio (2010) obtained $14.68 \pm 1: 56 \mathrm{~mm}$ on the right and 14:44 \pm 1:43 mm on the left side in Brazilian skulls. The results obtained in this study (Table I) are similar to those obtained with Nigerian and Caucasian skulls, and differ from those obtained with skulls Indian, Chinese, Thai and Brazilian. In previous studies on skulls from different parts of India mean values for the GPF-MSP distance with little variation among them have been reported (Westmoreland \& Blanton; Ajmani; Saralaya \& Nayak). However, in Brazilian skulls, comparing the results of this study to those of Chrcanovic \& Custodio, the variation was significant.

The GPF-PBHP distance also showed variability, ranging from $1.9 \mathrm{~mm}$ to $4.86 \mathrm{~mm}$. In Indian skulls, Westmoreland \& Blanton obtained $1.9 \pm 0.04 \mathrm{~mm}$ on both sides, Ajmani obtained $3.7 \pm 1.15 \mathrm{~mm}$ on the right side and $3.7 \pm 1.38 \mathrm{~mm}$ on the left side, and Saralaya \& Nayak obtained $4.2 \pm 0139 \mathrm{~mm}$ on the right side and $4.2 \pm 0133$ $\mathrm{mm}$ on the left side. Wang et al. found $4.11 \mathrm{~mm}$ in Chinese skulls, Ajmani $03.05 \pm 0.21 \mathrm{~mm}$ on both sides in Nigerian skulls, Jaffar \& Hamadah $4.86 \pm 1.15 \mathrm{~mm}$ in Caucasian skulls, and Methathrathip et al. $2.1 \pm 1.3 \mathrm{~mm}$ in both genders, $2.2 \pm 1.5 \mathrm{~mm}$ in male and $1.9 \pm 1.0$ in female Thai skulls. The results of this study (Table II) are very close to those obtained by Chrcanovic \& Custodio, who found 3:39 \pm 1.11 $\mathrm{mm}$ in Brazilian skulls, and also to those obtained in Nigerian skulls, differing from those obtained in Indian, Chinese, Caucasian and Thai skulls. The GPF- PBHP distance varied in Indian skulls (Westmoreland \& Blanton; Ajmani; Saralaya \& Nayak), but did not vary in Brazilian skulls comparing the present results to those of Chrcanovic \& Custodio.

Regarding the GPF shape, the results (Table III) confirm the ovoid pattern as predominant, obtained in previous studies in Chinese, Thai and Caucasian skulls (Cheung et al. 1998; Jaffar \& Hamadah; Methathrathip et al.), but are distant in absolute numbers. In Caucasian skulls Jaffar \& Hamadah obtained $97.08 \%$ ovoid-shaped GPF, and in Thai skulls Methathrathip et al. obtained $82.4 \%$ ovoid, $12.8 \%$ lancet or slit, and $4.8 \%$ round-shaped.

LOPES, P. T. C.; SANTOS, A. M. P. V.; PEREIRA, G. A. M. \& OLIVEIRA, V. C. B. D. Análisis morfométrico del foramen palatino mayor en cráneos de individuos adultos del sur de Brasil. Int. J. Morphol., 29(2):420-423, 2011.

RESUMEN: El foramen palatino mayor (FPM) da paso al nervio palatino mayor, responsable por la inervación de la región posterior del paladar. El conocimiento morfométrico del FPM es importante en las intervenciones anestésicas requeridas durante los procedimientos quirúrgicos maxilofaciales. El objetivo de este estudio fue evaluar la ubicación y la forma del FPM en cráneos de individuos adultos del Sur de Brasil. Se estudiaron 65 cráneos de hombres y 29 de mujeres, midiéndose la distancia desde el centro del FPM al plano mediano (PM) y al margen posterior del paladar duro (MPPD), utilizándose un cáliper digital y una regla milimétrica. La distancia promedio de FPM-PM en los lados derecho e izquierdo de los cráneos de hombres fue de 15,6 mm y 15,4 mm, respectivamente, y en los cráneos de mujeres, fue de 15,63 mm en el lado derecho y 15,47 mm en el izquierdo. La distancia media de FPM-MPPD en el lado derecho fue de 3,5 mm en cráneos de hombres y 3,1 mm en cráneos de mujeres y en el lado izquierdo de 3,6 mm y 3,2 mm en cráneos de hombres y mujeres, respectivamente. La prueba t de Student no mostró diferencias significativas en los promedios de las dos distancias (FPM-PM y FPM-MPPD), comparando sexos y lados. La forma ovoide del FPM fue predominante, seguida de las formas de hendidura y redonda. Este estudio proporciona comparaciones de datos étnicos, que pueden ayudar a la clínica en anestesia oral y maxilofacial.

\section{PALABRAS CLAVE: Foramen palatino mayor; Cráneos; Poblacion Brasileña; Osteometría.}

\section{REFERENCES}

Ajmani, M. L. Anatomical variation in position of the greater palatine foramen in the adult human skull. J. Anat., 184:635-7, 1994.

Castro, S. V. Anatomia fundamental. $3^{\text {a }}$ Ed. São Paulo, McGraw-Hill, 1985.

Cheung, L. K.; Fung, S. C.; Li, T. \& Samman, N. Posterior maxillary anatomy: implications for Le Fort I osteotomy. Int. J. Oralmaxillofac. Surg., 27:346-51, 1998.
Chrcanovic, B. R. \& Custódio, A. L. N. Anatomical variation in the position of the greater palatine foramen. J. Oral Sci., 52:109-13, 2010.

Ferreira, S. S.; Reis, L. R.; Gomes, J. C. \& Ferreira Junior, S. S. Análise do foramen palatinum majus e canalis palatinus major no esplancnocrânio humano, para acesso ao bloqueio do nervus maxilaris. Acta Biol. Par., 19:1$19,1990$. 
LOPES, P. T. C.; SANTOS, A. M. P. V.; PEREIRA, G. A. M. \& OLIVEIRA, V. C. B. D. Morphometric analysis of the greater palatine foramen in dry Southern Brazilian adult skulls. Int. J. Morphol., 29(2):420-423, 2011.

Hamilton, W. J. Tratado de anatomia humana. $2^{\mathrm{a}}$ ed. Rio de Janeiro, Interamericana, 1982.

Heidegger, G. W. Atlas de anatomia humana. $2^{\mathrm{a}}$ ed. Rio de Janeiro, Guanabara Koogan, 1972.

Jaffar, A. A. \& Hamadah, H. J. An analysis of the position of the greater palatine foramen. J. Basic Med. Sci., 3:24$32,2003$.

Lockhart, R. D.; Hamilton, G. F. \& Fyfe, F. W. Anatomia do corpo humano. 2a Ed. Rio de Janeiro, Guanabara Koogan, 1983.

Methathrathip, D.; Apinhasmit, W.; Chompoopong, S.; Lertsirithong, A.; Ariyawatkul, T. \& Sangvichien, S. Anatomy of greater palatine foramen and canal and pterygopalatine fossa in Thais: considerations for maxillary nerve block. Surg. Radiol. Anat., 27:511-6, 2005 .

Rizzolo, R. J. C. \& Madeira, M. C. Anatomia facial com fundamentos de anatomia sistêmica geral. $2^{\mathrm{a}}$ Ed. São Paulo, Sarvier, 2006.

Saralaya, V. \& Nayak, S. R. The relative position of the greater palatine foramen in dry Indian skulls. Singapore Med. J., 48:1143-6, 2007.

Sujatha, N.; Manjunath, K. \& Balasubramanyam, V. Variations of the location of the greater palatine foramina in dry human skulls. Indian J. Dent. Res., 16:99-102, 2005.

Wang, T. M.; Kuo, K. J.; Shih, C.; Ho, L. L. \& Liu, J. C. Assessment of the relative locations of the greater palatine foramen in adult Chinese skulls. Acta Anat., 132:182-6, 1988.

Westmoreland, E. E. \& Blanton, P. L. An analysis of the variations in position of the greater palatine foramen in the adult human skull. Anat. Rec., 204:383-8, 1982.

\author{
Correspondence to: \\ Paulo Tadeu Campos Lopes \\ Human Anatomy Laboratory \\ Brazilian Lutheran University \\ Av. Farroupilha, 8001, CEP 92425-900 \\ Canoas, RS \\ Brazil \\ Email: pclopes@ulbra.br \\ Received: 08-11-2010 \\ Accepted: 16-03-2011
}

